\title{
Cockcroft-Gault Formula
}

National Cancer Institute

\section{Source}

National Cancer Institute. Cockcroft-Gault Formula. NCI Thesaurus. Code C161342.

A formula to estimate creatinine clearance that takes into account sex, age, weight, and serum creatinine $(\mathrm{SCr}) . \mathrm{CCr}=(140-\mathrm{Age}) \times \mathrm{Wgt}(\mathrm{Kg}) / 72 \times \mathrm{Crt}(\mathrm{mg} / \mathrm{dL}) \times 1$ (if M) or 0.85 (if F), for conventional units. $\mathrm{CCr}=(140$ - Age) $\times$ Wgt (Kg) / 72xCrt (MCMOL/L) $\times 88.4 \times 1$ (if M) or 0.85 (if F) [lf Wgt is in lbs; Wgt (Kg) = Wgt (lbs) x 0.45], for SI units. (Cockcroft, D.W. and M.H. Gault. Prediction of creatinine clearance from serum creatinine. Nephron. 1976. 16(1):31-41.) 